\title{
Ideas, coalitions and compromise: reinterpreting EU-ETS lobbying through
}

\author{
discursive institutionalism
}

\section{Oscar Fitch-Roy, Jenny Fairbrass and David Benson}

\begin{abstract}
Collective political action among divergent interest groups is not always easy. It requires coordination, compromise and, often, the persuasive action of a policy entrepreneur. Coalition strategies are often shaped by participants' skill in mobilising ideas. Business-environmental coalitions - often considered 'strange bedfellows' - have proved to be important in emissions trading policy-making. In 2013, chronically low emissions prices meant that the EU's climate policy flagship, the EU-ETS, was holed beneath the waterline. But, within two years and against the odds, ambitious reforms were agreed to steady the ship. Crucial to the rescue were the actions of a pro-ETS business lobby, orchestrated by environmentalists. We draw on thirty-two in-depth interviews to construct a discursive institutionalist account of collective interest representation in relation to the reforms. We highlight the ability of policy entrepreneurs to fashion a 'change-but-no-change' pro-reform narrative attractive to businesses, despite the fact that such discursive strategies risked marginalising alternative and more disruptive ideas.
\end{abstract}

Keywords: Climate policy; Emissions trading; Energy policy; Interest representation; Policy entrepreneurship; Strange bedfellow coalitions 


\section{Introduction}

Since its introduction in 2005, Europe's primary climate change mitigation instrument, the European Union Emissions Trading System (EU-ETS), has undergone successive reform (Skjærseth and Wettestad 2010). One dramatic and politically fraught episode followed a collapse in the price of allowances in 2012-2013 that necessitated the 'rescue' of the instrument through substantial restructuring. Support in the form of 'backloading' was agreed in 2013, and in 2015, a 'market stability reserve' (MSR) was introduced: measures subsequently argued to have stabilised the instrument (Wettestad 2014; Wettestad and Jevnaker 2016). The success of the EU-ETS 'rescue mission' depended on timing, compromises at national and EU levels, and, importantly for this paper, interest group activity (Wettestad and Jevnaker 2016: 106). While the relative importance of interest groups in securing the reforms is debatable, that it was politically possible at all, can be partly attributed to the support of key business actors (Jevnaker and Wettestad 2017: 119). As we argue below, this support resulted from deliberate and concerted coalition-building efforts among interest groups, involving close collaboration between businesses and environmental groups, traditionally considered 'strange bedfellows'.

Networking has long been considered fundamental to interest representation and has been subjected to academic enquiry for decades (Heclo 1978; Richardson 1994; Mahoney 2007). Such activity can range from informal networks to highly formalised arrangements such as trade associations (ibid.). Somewhere between these two extremes lies ad-hoc, issue-specific coalitions (Mahoney 2007). Crucially, the emergence (or otherwise) of any lobbying coalition is a complex matter and may depend on multiple factors such as the policy problem and the resources available to interest groups (Holyoke 2009). Typically, such coalitions comprise members whose interests are manifestly aligned, for example, businesses located in the same industrial sector or non-governmental organisations (NGOs) with a common concern for policy areas such as the environment. Some coalitions, however, can be heterogeneous combining 
business and non-business organisations (Baumgartner et al. 2009; Beyers and De Bruycker 2017): so-called 'strange-bedfellow' coalitions. Arguably, those coalitions that include a diversity of interests can signal broader support for a policy position, and therefore potentially wield greater influence (Beyers and De Bruycker 2017; Phinney 2017). However, forming these coalitions requires agreement on goals and the means for goal attainment. The significant challenges posed by such arrangements could explain why such 'strange bedfellow' coalitions are less common than more homogenous groupings (Beyers and De Bruycker 2017).

Recent climate governance research shows that coalition-building often features in 'entrepreneurial' strategies by which skilled actors pursue 'power through organisation' (Boasson and Huitema 2017; Meckling 2011b: 29). Understood strategically, active coalitionbuilding emphasises the importance of coordinating actors or policy entrepreneurs who exercise agency by “...diffusing information, ensuring collaboration and motivating others" to join collective political enterprises (Boasson and Huitema 2017: 1348). When creating coalitions, policy entrepreneurs must align and re-order the preferences of a wider group (Fligstein and McAdam 2012). This is no small feat: to engender cooperation, policy entrepreneurs must simultaneously convince others that they are not narrowly self-interested, sense how others conceptualise their interests, the institutional environment, and their role within it and, ultimately, articulate a group identity to which a suitably broad range of actors can subscribe (Ansell 1997; Fligstein 2001). From this perspective, the establishment, maintenance and mobilisation of diverse lobbying coalitions is a discursive exercise in which policy entrepreneurs often play a crucial role (Fligstein and McAdam 2012: 50).

In this paper we explore the development of 'strange bedfellow' coalitions within the EU-ETS 'rescue mission' using a discursive institutionalist (DI) approach (Schmidt 2008; Schmidt 2010) to address one central question: What does DI reveal about the agency of policy entrepreneurs who sought to reform the EU-ETS between 2012 and 2015? The research 
employed a process-tracing method, combining extensive documentary analysis, observation of policy debates, and thirty-two semi-structured interviews ${ }^{1}$ conducted between 2015 and 2016. Interviewees included EU institution staff, NGOs, and businesses actively involved in EU climate and energy policy at that time. Of particular interest is the discursive actions of policy entrepreneurs in fashioning a highly influential 'strange bedfellow' coalition of businesses and environmental groups and the role they played in EU-ETS reform.

The remainder of this paper proceeds as follows. Section 2 elaborates our analytical framework, discursive institutionalism. Section 3 applies it to our selected case. Section 4 discusses and reflects on the findings and provides conclusions.

\section{Conceptual framework: discursive institutionalism and the role of policy entrepreneurs}

In using discursive institutionalism (DI) (Carstensen and Schmidt 2016; Schmidt 2002; Schmidt 2008; Schmidt 2010; Schmidt 2014; Schmidt 2017; Schmidt and Radaelli 2004), this article responds to an upsurge of recent research employing DI as an organising framework for public policy analysis (see for example: Buijs et al. 2014; Crespy and Schmidt 2014; den Besten et al. 2014; Fairbrass 2011; Lauber and Schenner 2011; Lorenzoni and Benson 2014; Schmidt 2014). In so doing, we seek to build on past scholarship by offering a more developed conception of the discursive nature of policy entrepreneurship.

It should be noted at this point that DI is the most recent manifestation of a wave of "new institutionalist' thinking that includes Historical Institutionalism (HI), Rational Institutionalism (RI), and Sociological Institutionalism (SI). In Schmidt's words (2010), DI differs from the other three new institutionalisms in terms of its objects of explanation, its logic of explanation, its problems of explanation and its approach to questions of continuity and change. In common with Schmidt (2008), we consider DI to be complementary to these theoretical approaches but 
also see it as a 'useful corrective' to them, given their inability to account for institutional change. A lack of space here precludes further detailed discussion of DI in comparison to other new institutionalisms but see Fairbrass (2011, pages 954-956) for a comparison between DI, HI, SI and RI and a summary of their relative merits and deficiencies. In short, arguably, the most significant difference between DI and earlier versions of new institutionalism is its focus on discursive interaction and the role of ideas in bringing about or preventing policy change. DI's particular novelty lies in perceiving ideas and discourse as dynamic and by emphasising the 'meaning' context of ideas themselves (Schmidt, 2010).

2.1 Institutions, ideas, and discursive interaction

Among DI's main contributions, as distinct from other 'new institutional' approaches, is its treatment of institutions as both 'given' (i.e. by providing the context in which actors think, speak and act) and 'contingent' (i.e. the result of actors thinking, speaking and acting). Institutions are therefore both simultaneously external 'constraining structures' and internal 'enabling constructs of meaning'. Consequently, actors' agency is exercised through both their 'background ideational abilities', which allow action within the constraints of a particular institutional context, and their 'foreground discursive abilities' that enable them to think outside the institutional context in which they are acting and to communicate critically to change or maintain those institutions (Schmidt 2008: 314; Schmidt 2017).

In DI, ideas may occur at several levels of generality: firstly, as policy ideas which are the most specific and detailed; secondly as programmatic ideas that underpin policy ideas and set out the problems to be solved by policies; and finally, as deeper philosophical ideas can be considered even more elemental than the other two levels and can be seen as 'deep core' ideas that are rarely contested apart from times of crisis (Schmidt 2008, 306). The last category 
represents the organising beliefs, mind-sets, tenets, and principles of knowledge and understanding on which society relies.

DI also distinguishes between 'cognitive' ideas (i.e. that tell us 'what is or what to do') and 'normative' ideas (i.e. that set out 'what one ought to do') (Schmidt 2008: 306). Cognitive ideas can provide the methods or procedures for political action. At the programmatic level, cognitive ideas may define the problems to be solved and indicate potential solutions. Cognitive ideas may also demonstrate how policy and programmatic level ideas can be interwoven with fundamentally deep core ideas. By contrast, normative ideas provide the values that connect to political action and serve to validate policies. They can also furnish the principles and beliefs that can link all three levels of ideas.

Finally, 'discourse' is the process by which actors interact and ideas are generated, deliberated and legitimated (Schmidt 2008; Schmidt 2010). These interactive processes may take two forms: 'coordinative' discourse among direct participants in the policy process, or 'communicative' discourse that links the policy process to a more general public (Schmidt 2008: 310-311). Participants in coordinative discourse are usually political élites: elected officials, civil servants and administrators, interest groups and think tanks (Schmidt 2002). Communicative discourse potentially encompasses a wider range of political actors (such as political leaders, policy forums, and informed publics) who bring ideas developed through coordinative discourse to the public for deliberation and legitimation. The relative importance of coordinative and communicative discourse is determined by complexities of the political system. For example, in 'compound polities' such as the EU, coordinative discourse is more important (Schmidt 2010; Schmidt 2013). Accordingly, in our research it is the coordinative communication surrounding the EU-ETS that provides our focal point. 


\subsection{Policy entrepreneurs and entrepreneurship}

Although the DI literature does imply a role for policy entrepreneurs who:

"... serve as catalysts for change as they draw on and articulate the ideas of discursive communities and coalitions" (Schmidt 2008: 310),

this aspect of the framework remains under-specified. Given our particular focus on coordinative, interactive processes associated with the EU-ETS reform and the policy entrepreneurs who participated in it, we propose a more developed conceptualisation of their roles and activities. We contend that greater clarity and depth of understanding about the role entrepreneurs play in the coordinative interactive processes associated with policy-making strengthens DI as an analytical framework.

Policy entrepreneurs are potent political actors who invest time and effort into identifying, analysing, and advancing particular policy problems on the policy agenda and offering policy solutions (Béland and Katapally 2018). They are often identified by their ability to achieve greater results than their material resources may suggest, i.e. doing 'more with less' or 'punch[ing] above their weight' (Boasson and Huitema 2017: 1344). Entrepreneurs may play different formal or informal roles in the policy process: as elected officials, staff or members of political parties, interest groups, and think tanks. Entrepreneurial strategies can be categorised as 'structural' attempts to reorder the distribution of authority and information, or 'cultural-institutional' attempts to manipulate ideas and their perception through discursive actions such as 'framing' (Boasson and Huitema 2017). Successful policy entrepreneurship requires the framing of a problem, having a solution prepared and a keen sense of timing (Cairney 2018; Fitch-Roy and Fairbrass 2018).

A role clearly exists for policy entrepreneurship in creating lobbying coalitions. Within specific institutional contexts, they are skilled actors that use their discursive abilities to bring about 
cooperation within and between disparate groups, build and maintain institutions and reshape the social order through creating new forms of meaning attractive to others (Fligstein 2001: 106). This may necessitate developing narratives or stories that appeal to others':

"...identity, belief, and interests, while at the same time using those same stories to frame action against various opponents" (Fligstein and McAdam 2012: 50).

However, defining entrepreneurship purely through the personal attributes of a hypothesised policy entrepreneur may overstate the agency of individuals and underplays the vital importance of social context (Boasson and Huitema 2017). As Schmidt (2008: 320) points out, the agency afforded to élite entrepreneurial actors to shape the communicative discourse extends only as far as it can be sustained through bottom-up communicative legitimation. Nevertheless, we maintain that discursive entrepreneurship evidently plays an important role within the rarefied world of lobbying and advocacy. Typically, policy entrepreneurship requires particular skills and capabilities such as (Mintrom and Luetjens 2017; Mintrom and Norman 2009; Mintrom and Thomas 2018):

- $\quad$ social acuity or the ability to understand others' perspectives;

- credibility gained either through a particular claim to knowledge or experience or the ability to surround oneself with credible supporters;

- the ability to gain others' trust and build cohesive social units;

- tenacity, dogged determination to work towards long-term goals, in spite of setbacks.

In analysing the data collected for this paper, we pay particular attention to the role of entrepreneurs in engineering the EU-ETS reforms between 2012 and 2015. 


\section{Applying DI to the EU-ETS rescue mission}

\subsection{The EU-ETS and institutional context}

Implemented in 2005, the EU-ETS was the world's first and most comprehensive international greenhouse gas (GHG) cap-and-trade system and covers around half of EU emissions (European Commission 2016). The mere existence of a functioning EU-ETS is regarded as a major policy success for the European Union (Convery 2009; Oberthür 2011). Institutional embeddedness and the political capital sunk in its creation mean that the EU-ETS plays a central role in EU energy and climate policymaking (Bailey et al. 2011; Woerdman 2004). While the system continues to evolve, the immutable status of the principle of 'cap and trade' is often expressed by describing the EU-ETS as Europe's 'flagship' or 'cornerstone' climate policy (Braun 2009; Convery 2009; Groenenberg et al. 2008; Skjærseth and Wettestad 2010; Wettestad 2014). Within the European Commission, while DG Energy tended to support using multiple instruments in pursuit of climate policy goals, by 2015 the focus on emissions trading as the primary EU climate policy led to DG Clima being nicknamed "DG ETS” (Interview 2, 2015; Interview 11, 2015). The incoming Energy Commissioner Oettinger was perceived as closer to the business community and more industry-orientated that his predecessor (Buchan and Keay 2014; Bürgin 2015) to such an extent that some environmentalists referred to him as "Commissioner for the energy intensive industries", reflecting the "direct line" alleged to exist between him and heavy industry (Interview 8, 2015; Interview 30, 2016).

A decade after its conception, the performance of the EU-ETS had become troubling (Wettestad and Jevnaker 2016). During 2012 and 2013, oversupply of allowances led to prices falling below $€ 10$ per tonne, a level deemed too low to meaningfully impact energy sector investment decisions (European Commission 2014b; EWEA 2014; IETA 2012). Widespread concern arose about the instrument's ability to drive change (Interview 7, 2015; Interview 25, 2015; Hone 2017: 105). Following a heated debate among policy actors, the European 
Commission's proposed a reform package, first proposing 'backloading' ${ }^{2}$ or temporarily withholding allowances scheduled for market auction in 2012, with proposals for substantial, structural reform sketched out (European Commission 2012). In early 2013, however, the European Parliament narrowly rejected the relatively modest (and temporary) backloading proposals, leading commentators to speculate about the demise of the ETS (The Economist 2013). However, in an unexpected turnaround in mid-2013, the Parliament voted to accept a slightly amended backloading proposal ${ }^{3}$, with the final agreement between the Council and Parliament resulting in a Commission Regulation in February 2014 (European Commission 2014a). In parallel, the Commission developed proposals for permanent, structural ETS reform, seen as significant as renewed ambition emerged for climate and energy policy action after 2020. By January 2014, following substantial consultation and negotiation, plans were published for a 'Market Stability Reserve' (MSR) that allowed the number of marketable permits to vary according to the allowances in circulation (European Commission 2014c). A Commission MSR proposal was adopted in 2015 which is scheduled for operation in 2019 (European Commission 2014c; European Parliament 2014; Wettestad and Jevnaker 2016). Emerging from the same process, a revised EU-ETS Directive was proposed by the Commission, coming into force in April 2018 (European Union 2018).

That the EU-ETS was resuscitated first through backloading, and then MSR in just two years, and rehabilitated through revised legislation less than three years later, with little change in external conditions, required significant political negotiation and persuasion. Events in member states, the European Parliament and within the Commission all contributed to the reversal of fortunes (see Wettestad and Jevnaker 2016). While existing reports of the EU-ETS reform process ascribe a role to businesses and interest groups, it is generally seen in terms of disunity in opposition to reform, with the energy intensive industries' failure to build meaningful support for their position enabling the reforms to proceed (Jevnaker and Wettestad 2017: 117). 
However, we suggest that the divide between 'pro' and 'anti' businesses was reinforced by significant coordination of rescue efforts among pro-ETS businesses. On the surface, such coordination seems unsurprising, but the fact that the grouping from which it emerged included a wide range of businesses, and that much of the organising effort was undertaken by an environmental group, raises the question of how and why this happened. In the following sections, we examine this 'strange bedfellow' coalition.

\subsection{Competing set of ideas}

Here we outline the primary ideas that constituted the discourse among EU energy and climate interest groups between 2012 and 2015, as identified by interviewees. The first idea is 'climate action', a set of largely normative assumptions about the rationale for and, urgency and nature of, climate policy. The second is ‘technology neutrality', an ostensibly cognitive assessment of the role of public policy in 'picking winners' either by specifying technology choices or by allowing markets to determine technology outcomes.

\subsubsection{Climate action}

Scientific consensus concludes that the earth's climate is changing and that human activity, principally carbon dioxide emissions largely associated with energy supply, is responsible (IPCC 2014; The Royal Society 2017). Despite some noisy interventions from so-called 'climate-denialists', the acceptance of the scale and urgency of the problem is well established, especially among the European élites engaged in EU policymaking. Nevertheless, ideas about whether and how to engage in 'climate action' to mitigate the risks associated with a changing climate are not monolithic, neither across society, nor within particular social settings such policy communities (Fitch-Roy et al. 2018). Contrasting material and cultural factors create differing interpretations of the reality of climate change, as well as the causal factors linking policy action and outcomes (Dietz et al. 2007). 
The issue of EU-ETS reform reflects years of entrenched division between Europe's heavy industries such as steel, aluminium, and cement on one side and other less carbon-intensive manufacturing and service industries, civil society groups, 'new' energy industries and the electricity industries on the other (Fitch-Roy and Fairbrass 2018). The two sides have starkly divergent material interests. The electricity industry, for example, may pass the costs of carbon trading onto consumers for whom demand is especially price-inelastic while the steel industry is globally mobile and competes with manufacturers not covered by the EU-ETS (Juergens et al. 2013). The energy intensive industries have fought, with some success, to be treated as a special case within the EU-ETS, largely by raising concerns about 'carbon leakage', a postulated race-to-the-bottom process by which industry leaves the EU seeking lower regulatory costs (Wettestad 2009).

This material exceptionalism of the energy intensive industries, combined with differences in approach to the social interaction required to discuss policy, creates a situation where the preferred types of policies are disputed among actors alongside no common understanding of the basic diagnosis. Indeed, the perceived motives of the 'others' generates mutual suspicion. Energy intensive industry lobbyists may perceive that while they argue to keep industry and jobs in Europe, the 'opposition' are either cynically or ideologically determined to push those industries away. Concurrently, energy intensive industries are considered 'dinosaurs' which either do not comprehend the seriousness of the climate challenge or have callous disregard for its implications. While neither of these caricatures is objectively correct, the topic of EU-ETS reform reveals the deep gulf between the energy intensive industries, resistant to EU-ETS reform, and other European businesses and NGOs.

\subsubsection{Technology neutrality}

Meanwhile, business and civil-society actors that do accept their role is tackling climate change are divided by attitudes to 'technology neutrality'. The idea that it is better to create a price for 
carbon, to 'internalise' its societal costs and allow markets to respond with appropriate mitigations has long been discussed in climate change and sustainable energy debates (Azar and Sandén 2011). However, technology-neutrality and its role in sustainable energy policy has consistently divided opinion (Azar and Sandén 2011; Jacobsson et al. 2009). Throughout the 1990s and 2000s, for example, debate raged about whether effective renewable energy support policies were technology-neutral and whether the market should 'select' which technologies should be brought forward or whether a more targeted strategy should be adopted in which chosen technologies were supported (Lauber and Schenner 2011; Mitchell et al. 2006). In EU climate and energy policy, technology differentiation is preferred by industries such as renewable energy and energy efficiency equipment producers, as well as environmental groups, while technology-neutral climate policies that emphasise emissions pricing through the EU-ETS are preferred by electricity producers and other businesses (Boasson and Wettestad 2013).

\subsection{Interactive processes: interest group cooperation, coalition building and conflict}

The energy intensive industries supported by an umbrella organisation, BusinessEurope, initially attempted to resist EU-ETS reform and, once it became inevitable, they sought concessions (Jevnaker and Wettestad 2017).

However, other business actors supported reform. Established in 2011, an informal, ad-hoc and fluid grouping of more than 40 organisations, the 'Friends of ETS' (FoETS) coalition brought together multiple actors (Interview 1, 2015; Interview 21, 2015). Electricity producers, the wind industry, a furniture brand, think-tanks, gas companies, manufacturers of energy efficiency equipment, and energy generation plant were all represented alongside industry groups Eurelectic and Eurogas. Although not visible on the group's formal publications, the coalition was created and directed by Change Partnership, a Brussels based climate NGO, with a Chief Executive Officer (CEO) whose political judgment and policy knowledge was highly 
regarded (Interview 8, 2015; Interview 15, 2015; Interview 21, 2015; Interview 26, 2015; Interview 31, 2016). With modest resources, the coalition was financially supported by the European Climate Foundation (ECF) among other donors (Interview 30, 2016; Change Partnership 2014).

At the time of FoETS' creation, there was substantial resistance to efforts being made by NGOs aimed at enlarging the ambition of EU climate policy through increasing headline GHG emissions reduction from $20 \%$ to $30 \%$ (Interview 2, 2015). Despite enthusiastic rhetoric about climate action, influential companies such as Shell were hesitant to commit to the increase, possibly because they were unable to accurately assess the commercial implications (Interview 30, 2016). Meanwhile, Poland (repeatedly) vetoed the Commission's proposals in the 'Roadmap for moving to a competitive low carbon economy in 2050' (Keating, 2012). Given the seemingly insurmountable challenge of increasing the headline GHG emissions reduction target, a key action of the nascent FoETS was consequently to reassess the options for increasing the stringency of EU climate policy, concluding that actions intended to strengthen the EU-ETS would be palatable to most businesses (Interview 21, 2015; Interview 30, 2016).

Although the economic crisis and Europe's tarnished climate leader role following the 2009 UN climate conference in Copenhagen meant that little appetite existed within either the Commission or the European Council to begin major reform of the EU-ETS (Interview 30, 2016; Wettestad and Jevnaker, 2016), the 'Roadmap for moving to a competitive low carbon economy in 2050' did acknowledge that implementing energy efficiency targets may mean that:

“...appropriate measures need to be considered, including recalibrating the ETS by setting aside a corresponding number of allowances..." (European Commission, 2011. p11 - authors' emphasis). 
Observing that one of the main EU energy and climate policy tasks was the drafting of an Energy Efficiency Directive to allow implementation of the target set in 2007, FoETS mustered support for the 'set-aside' principle from across the business community, including utilities such as ENEL, and oil and gas company Shell by promoting a causal narrative about the interaction between energy efficiency measures and the EU-ETS in which greater energy efficiency threatened the functioning of emissions trading by compounding the oversupply of allowances. Effectively, FoETS reframed the debate about the Energy Efficiency Directive to focus on the impact of such efficiency measures on the EU-ETS, much to the frustration of advocates for energy efficiency who saw the dominance of the EU-ETS in debates about climate and energy policy as detrimental to the goal of increased energy efficiency:

"[The] ETS [is] a kind of a dogma and this we, as an efficiency community, have always been very wary of because it's a sacred cow; you can't touch the ETS, despite the fact that it has completely failed"..."there is a lot of emotional effort and personal reputation buried in the Emissions Trading Scheme, which, from our perspective, has been a complete failure because it hasn't provoked any swing towards more efficiency measures across Europe."..."I suppose we all have that tendency to hold onto our babies and to cherish them and not be able to open our eyes and see objectively where they're really have their effect or not. But this one seems blatantly obvious to me it's a failure but that's my view." (Interview 12, 2015)

Similarly, other environmental organisations had misgivings about the strategic choice to pursue EU-ETS reform, believing that:

“...they were focusing either exclusively or in an unbalanced way on ETS reform to the detriment of other areas" (Interview 33, 2016). 
Despite being aware of how unpopular the strategy would be with peers in the environmental community, the FoETS and its network collectively lobbied the Commission, to reflect this concern in the Energy Efficiency Directive, achieving some success:

"In the implementation of the $20 \%$ energy efficiency target, the Commission will have to monitor the impact of new measures on Directive 2003/87/EC establishing the Union's emissions trading scheme (ETS) in order to maintain the incentives in the emissions trading system..." (European Commission, 2012b. Para. 55).

The recognition in the Energy Efficiency Directive that the EU-ETS may require attention gave the campaign substantial momentum, since having acknowledged the potential connection, the Commission had little choice but to engage with ideas for EU-ETS reform, including 'backloading', a practical means of creating the set-aside with legal precedent established through the front-loading provisions (Interview 21, 2015).

The collaboration enabled coordination between renewable energy, oil and gas and electricity producers. In a letter sent by them in June 2012 to Commissioners they expressed their support for backloading ahead of the Commission's proposals and the collective reaction to the proposals in July (3M et al. 2012; Euractiv 2012). Although the initial rejection by the European Parliament was a setback, the group continued to be closely coordinated, in both message and tactics, as the various businesses sought to persuade Members of the European Parliament (MEPs) and member states throughout the legislative process. By establishing trust among a small group of businesses through close social interaction, the coalition presented a strong 'green-growth' or 'environmental capitalism' narrative about the crucial role of the EUETS and the urgent need to reform it (Interview 1, 2015; Interview 10, 2015).

Having first persuaded the powerful electricity utility ENEL to adopt its position in favour of backloading, which gave credibility and the 'perception of momentum', the FoETS coalition's 
messaging strategy was to emphasise the 'special' status of the EU-ETS as the EU's climate policy flagship to increase the salience of the instrument's perceived failure, and its implications for climate action, to secure the most ambitious reform possible. In addition to the sunk political costs associated with its establishment, support for maintaining the instrument's status was especially strong in DG Clima, responsible for drafting the reform legislation (Interview 2, 2015; Interview 33, 2016). Consequently, differences between DG Energy and DG Clima on the EU-ETS were deliberately cast as a direct confrontation between the heavy industry-oriented Energy Commissioner and DG Clima (Interview 30, 2016). Significant to the group's strategy was emphasising the perceived failure of the ETS, framing it as the most pressing problem facing EU climate and energy policy, and making securing reform the overriding priority (Interview 30, 2016).

That such a range of businesses was able to align with it shows the power of this essentially technology-neutral narrative about the need for EU-ETS reform. Electricity utilities seeking to maintain market share in the face of competition from renewables, gas companies seeking to improve their competiveness against (even) dirtier oil and coal producers, and consumer goods firms advocating for the most 'efficient' policy all invoked the idea.

However, in 2013, the climate and energy policy community in Brussels simultaneously had two major policy developments in play. Alongside the EU-ETS reform legislation, advocacy groups were seeking to influence the 2030 Climate and Energy Framework, a package of targets designed to maintain the EU's trajectory towards deep decarbonisation by 2050. As well as opening up political space for bargaining between members states (Jevnaker and Wettestad 2017), it also complicated building a lobbying coalition to support EU-ETS reform. The strategy of creating a sense of crisis in the trading system clashed with the goals of actors, such as the renewable energy industry, who consistently argued that the EU-ETS was not the 
'be-all-and-end-all' of EU climate and energy policy and that a broader basket of policies was more appropriate:

"[They] wanted to keep on putting in language saying multiple targets. We kept on saying it's only the ETS that counts. "..." [So] this was the sacrifice we had to make. It was either to get [renewables actors], or we can go and get more people who [have] more power, and I'd rather talk to the guys who've got more [power]." (Interview 30, 2016)

Nevertheless, the coalition and the coordination between electricity producers, NGOs and other businesses appears successful and is credited with influencing both the short-term goal of backloading and the longer-term MSR fix for the ETS (Interview 8, 2015; Interview 30, 2016; Interview 31, 2016; Wettestad and Jevnaker 2016). The FoETS, by recruiting key businesses and NGOs, was a lobbying 'dream team'. The legitimacy of energy utilities with millions of customers and hundreds of thousands of employees, the campaigning nous of seasoned environmentalists, combined with a shared contacts book, all coordinated by a doggedly determined entrepreneur, appears formidable and decisive.

\section{Discussion and conclusions: the role and limits of climate policy entrepreneurship}

A direct correlation between the 'strange-bedfellow' coalition reported above and policy change is unlikely to be unequivocally demonstrable. However, the concerted efforts of business and other interest groups between 2012 and 2015, under the banner of Friends of ETS corroborates existing accounts of the EU-ETS reform process (Jevnaker and Wettestad 2017). Based on the preceding account, it is clear that as a result of the 'Friends of ETS' coalition, the electricity industry was more assertive, more organised and 'had more friends' than it would otherwise. Following the setback of the 2009 UN climate conference in Copenhagen, the coordinator tenaciously pursued new opportunities to shape EU climate policy. The coalition 
demonstrated keen social acuity in identifying a policy position to which policy actors with divergent interests could subscribe. This broad appeal, combined with the fostering of a highly sociable atmosphere around the coalition, allowed recruitment of credible businesses actors that could speak on behalf of the group. Although a small NGO with limited resources, through the creation of Friends of ETS, it was able to 'punch above its weight'; a hallmark of policy entrepreneurship (Boasson and Huitema 2017).

From a discursive institutionalist perspective, the coalition deployed background ideational abilities to navigate and exploit the extant institutional environment. By emphasising the difficulties faced by the EU-ETS, the coalition created and promoted a powerful story about EU-ETS reform as not only one of several climate strategies, but, in the contemporary institutional context the only viable strategy. The adoption of a position relative to technology neutrality reflects an appreciation of the ideational divide between DG Energy and DG Clima, the fundamentally immutable nature of the EU-ETS, and differing commercial interests. Foreground ideational abilities, meanwhile, were deployed to create a mobilising narrative that set FoETS as a challenger to the perceived heavy industry champion Energy Commissioner. The normative idea of the 'rightness' of climate action was used to frame group membership in opposition to the heavy-industrial 'bad guys', represented by energy commissioner Oettinger, with whom few self-identified progressive policy specialists would choose to be associated.

In addition to this 'my enemy's enemy is my friend' approach to galvanising support for action, technology neutrality, a cognitive idea about what constitutes effective policy, was used to broaden the appeal of the coalition, allowing the participation of businesses previously wary of supporting a conventional environmentalist position. In particular, electricity and gas businesses were able to square the technology neutral narrative with their commercial interests. At the same time, groups such as renewable energy and energy efficiency companies that had 
traditionally resisted a technology neutral policy narrative and were already in a weak political position due to the ongoing economic crisis, were further marginalised.

The discursive entrepreneurial activity that we have revealed and analysed was likely to have played a key role in securing EU-ETS reforms, backloading and the market stability reserve. However, in doing so, it also marginalised more plural policy narratives about the 2030 targets, rooted in understandings of systemic change that emphasised the value of strategic technology support and further entrenched a 'green capitalism' approach to climate policy (Fitch-Roy et al. 2018). While the implications for future EU climate and energy policy are unclear, the ability of discursive entrepreneurship by interest groups to affect substantial change will continue to be academically relevant.

At this point, it is important to reflect on the types of ideas in play by returning to Schmidt's typology of levels of ideational generality (Schmidt 2008; Schmidt 2017). The coalition had a discernible impact at the detailed 'policy level' and it operationalised ideas that exist at the 'programmatic level' by diagnosing the problems of the EU-ETS as the climate policy problem to be solved it also created new norms of collaborative working between NGOs and businesses in pursuit of change. We can say that this 'strange bedfellow' coalition was able to create and maintain an ideational shift within the policy community through discursive means.

However, it is surprising that an environmental actor should so enthusiastically pursue a strategy that not only avoids challenging the inherent contradictions of the idea of climatefriendly market-capitalism (which we need not rehearse here), but goes further in wholeheartedly embracing the idea that markets alone can fix the climate problem, albeit for pragmatic, strategic reasons. This is especially pertinent given firstly the demonstrably lacklustre performance of the EU-ETS in driving change to-date and secondly, the radical roots of environmental activism that informs the identity of many environmental activists (Kashima 
et al. 2014). Business entrepreneurs and other élites adopting green credentials, whether for principled reasons or 'green impression management' purposes are quite familiar (Nye and Owens 2008; Prudham 2009). It is somewhat unsettling, however, to observe movement in the opposite direction.

Finally, if politics is about "who gets what, when and how" (Lasswell 1936), the question of power comes to the fore. It is quite possible to interpret the case outlined above as one of shrewd compromise. By accepting the world (and its institutions) 'as it is', the coalition's founders brought about pro-environmental change by using the power of incumbent interests against them, skilfully manipulating ideas through discourse. However, this immediately begs the question 'at what cost?' By adopting and amplifying a narrative about environmental policy-change acceptable to a wide range of businesses, other accounts of how policy can be used to tackle climate change were marginalised. This observation opens up the possibility of an alternative interpretation, in which business successfully co-opted and instrumentalised the environmental movement in pursuit of a 'change-but-no-change' outcome.

So, in conclusion, while the 2012-2015 EU-ETS reform episode has been meticulously analysed, the role of interest group coordination has been somewhat overlooked (Jevnaker and Wettestad 2017). We have addressed that gap. Our research shows that the speed with which reform of EU-ETS was agreed and implemented in 2012-2014 was partially dependent on cooperation among pro-ETS businesses. Policy entrepreneurship through discursive framing of EU-ETS reform as 'the only (climate) game in town' enabled cooperation between NGOs, business and key parts of the bureaucracy to argue for change. Whether or not this was an astute strategic choice by the environmentalist at the helm of the coalition or a win for businesses less keen on radical or ambitious climate policy, is not immediately obvious. 
The DI framework illuminates the significance of the strategic discursive action that differentiates between an actor's ability to read the terrain (i.e. background ideational abilities), and their ability to critically engage with that terrain, or redraw the map (i.e. foreground discursive abilities). The policy entrepreneurship explored here hinges on the relative importance of these two abilities and prompts further research into how heterogeneous collaborations achieve policy change. The challenges of defining and identifying policy entrepreneurship and its agents in terms of personal characteristics are well known (Boasson and Huitema 2017). However, in cases such as the one depicted here, even though many reasonable definitions of policy entrepreneurship would identify the activity as entrepreneurial, merely having the 'right characteristics', successfully using the strategies and playing the role of entrepreneur may lead to fundamentally ambiguous outcomes. Consequently, further research is required in order to more clearly understand the constraints on entrepreneurial success and the role of policy entrepreneurship as a discursive activity.

\section{Notes}

1. Respondents were asked to provide their perceptions of the policy context and background, an account of the reform processes in question, their tactics for engaging with the policy process, including membership of lobbying coalitions, and the observed tactical strategies of others. Interview transcripts were then coded for ideas, group membership, types of actor and engagement strategy. In counteracting 'expansiveness bias' commonly encountered with potential policy entrepreneurs (Beyers et al. 2014), reports of success were cross checked against other accounts of the same phenomena. The methods used in collecting and analysing the data were evaluated against criteria of credibility, transferability, dependability and confirmability (Lincoln and Guba 1985; Shenton 2004). 
Accepted to Journal of European Public Policy, 01/01/2019

2. Backloading mirrors the existing 'frontloading' provisions that enabled industries (primarily electricity producers) to procure allowances ahead of compliance periods.

3. Decision No 1359/2013/EU

\section{The authors}

Oscar Fitch-Roy is a research fellow in the Energy Policy Group at the University of Exeter,

Treliever Road, Penryn, UK. o.fitch-roy@exeter.ac.uk;

Jenny Fairbrass is a senior lecturer in Norwich Business School at the University of East Anglia

David Benson is a senior lecturer in the Department of Politics at the University of Exeter

\section{Acknowledgments}

The authors are grateful to the journal editors and to three anonymous reviewers for their thorough reviews and constructive comments on an earlier version of this paper. 
Accepted to Journal of European Public Policy, 01/01/2019

\section{References}

3M et al. (2012) Letter to Commissioners in support of backloading, 2012, available at https://www.endseurope.com/docs/120627c.pdf (accessed September 2018).

Ansell, C. K. (1997) 'Symbolic Networks: The Realignment of the French Working Class, 1887-1894', American Journal of Sociology 103(2): 359-390.

Azar, C. and Sandén, B. A. (2011) 'The elusive quest for technology-neutral policies', Environmental Innovation and Societal Transitions 1(1): 135-139.

Bailey, I., Gouldson, A. and Newell, P. (2011) 'Ecological Modernisation and the Governance of Carbon: A Critical Analysis', Antipode 43(3): 682-703.

Baumgartner, F. R., Berry, J. M., Hojnacki, M., Kimball, D. C. and Leech, B. L. (2009) Lobbying and Policy Change: Who wins, who loses, and why, Chicago: University of Chicago Press.

Béland, D. and Katapally, T. R. (2018) 'Shaping Policy Change in Population Health: Policy Entrepreneurs, Ideas, and Institutions', International Journal of Health Policy and Management 7(5): 369-373.

Beyers, J., Braun, C., Marshall, D. and De Bruycker, I. (2014) 'Let's talk! On the practice and method of interviewing policy experts', Interest Groups \& Advocacy 3: 174-187.

Beyers, J. and De Bruycker, I. (2017) 'Lobbying makes (strange) bedfellows: Explaining the formation and composition of lobbying coalitions in EU legislative politics', Political Studies $1-36$.

Boasson, E. L. and Huitema, D. (2017) 'Climate governance entrepreneurship: Emerging findings and a new research agenda', Environment and Planning C: Politics and Space 35(8): 1343-1361.

Boasson, E. L. and Wettestad, J. (2013) EU Climate Policy: Industry, Policy Interaction and External Environment, Oxford: Ashgate Publishing, Ltd.

Braun, M. (2009) 'The evolution of emissions trading in the European Union - The role of policy networks, knowledge and policy entrepreneurs', Accounting, Organizations and Society 34(3-4): 469-487.

Buchan, D. and Keay, M. (2014) The EU's new energy and climate goals for 2030: under- 
Accepted to Journal of European Public Policy, 01/01/2019

ambitious and over-bearing?, 2014, available at https://www.oxfordenergy.org/wpcms/wp-content/uploads/2014/01/The-EUs-newenergy-and-climate-goals-for-2030.pdf (accessed March 2014).

Buijs, A., Mattijssen, T. and Arts, B. (2014) "“The man, the administration and the counterdiscourse": An analysis of the sudden turn in Dutch nature conservation policy', Land Use Policy 38: 676-684.

Bürgin, A. (2015) 'National binding renewable energy targets for 2020, but not for 2030 anymore: why the European Commission developed from a supporter to a brakeman', Journal of European Public Policy 22(5): 690-707.

Cairney, P. (2018) 'Three habits of successful policy entrepreneurs', Policy and Politics 46(2): $1-16$.

Campbell, J. L. (2002) 'Ideas, Politics, and Public Policy’, Annual Review of Sociology 28(1): 21-38.

Carstensen, M. B. and Schmidt, V. A. (2016) 'Power through, over and in ideas: conceptualizing ideational power in discursive institutionalism', Journal of European Public Policy 23(3): 318-337.

Change Partnership (2014) Friends of ETS, 2014, changepartnership.org, available at http://www.changepartnership.org/campaigns/friendsofets/ (accessed July 2016).

Convery, F. J. (2009) 'Origins and development of the EU ETS', Environmental and Resource Economics 43(3): 391-412.

Crespy, A. and Schmidt, V. A. (2014) 'The clash of Titans: France, Germany and the discursive double game of EMU reform', Journal of European Public Policy 21(8): 1085-1101.

den Besten, J. W., Arts, B. and Verkooijen, P. (2014) 'The evolution of REDD+: An analysis of discursive-institutional dynamics', Environmental Science \& Policy 35: 40-48.

Dietz, T., Dan, A. and Shwom, R. (2007) 'Support for climate change policy: social psychological and social structural influences', Rural Sociology 72(2): 185-214.

Euractiv (2012) Brussels rolls out carbon market fix, 2012, available at https://www.euractiv.com/section/climate-environment/news/brussels-rolls-out-carbonmarket-fix/ (accessed July 2018). 
European Commission (2011) A Roadmap for moving to a competitive low carbon economy in 2050, Brussels: European Commission.

European Commission (2012a) The state of the European carbon market in 2012, 2012, doi:10.1093/rpd/ncr264.

European Commission (2012b) Directive 2012/27/EU on energy efficiency, 2012, doi:10.3000/19770677.L_2012.315.eng.

European Commission (2014a) Commission Regulation (EU) No 176/2014 of 25 February 2014 amending Regulation (EU) No 1031/2010 in particular to determine the volumes of greenhouse gas emission allowances to be auctioned in 2013-20, 2014, available at https://eur-lex.europa.eu/legalcontent/EN/TXT/PDF/?uri=CELEX:32014R0176\&from=EN (accessed July 2018).

European Commission (2014b) Impact Assessment - A policy framework for climate and energy in the period from 2020 up to 2030, 2014, available at http://ec.europa.eu/smartregulation/impact/ia_carried_out/docs/ia_2014/swd_2014_0015_en.pdf (accessed July 2015).

European Commission (2014c) Proposal for the establishment and operation of a market stability reserve for the Union greenhouse gas emission trading scheme and amending Directive 2003/87/EC, 2014, available at http://eur-lex.europa.eu/legalcontent/EN/TXT/PDF/?uri=CELEX:52014PC0020\&from=en (accessed November 2015).

European Commission (2016) The EU Emissions Trading System (EU ETS), Brussels.

European Parliament (2014) Decision of the European Parliament and of the Council concerning the establishment and operation of a market stability reserve for the Union greenhouse gas emission trading scheme and amending Directive 2003/87/EC, Brussels: EUR-Lex.

European Union (2018) Directive (EU) 2018/410 of the European Parliament and the Council - of 14 March 2018 - amending Directive 2003/87/ EC to enhance cost-effective emission reductions and low-carbon investments, and Decision (EU) 2015/ 1814, 2018, Official Journal of the European Union, doi:http://eurlex.europa.eu/pri/en/oj/dat/2003/1_285/1_28520031101en00330037.pdf. 
Accepted to Journal of European Public Policy, 01/01/2019

EWEA (2014) Position on the backloading proposal, Brussels.

Fairbrass, J. (2011) 'Exploring corporate social responsibility policy in the European Union: A discursive institutionalist analysis', Journal of Common Market Studies 49(5): 949-970.

Fitch-Roy, O., Benson, D. and Mitchell, C. (2018) 'Wipeout? Entrepreneurship, policy interaction and the EU's 2030 renewable energy target', Journal of European Integration.

Fitch-Roy, O. and Fairbrass, J. (2018) Negotiating the EU's 2030 Climate and Energy Framework, Cham: Palgrave Macmillan.

Fligstein, N. (2001) 'Social Skill and the Theory of Fields', Sociological Theory 19(2): 105125.

Fligstein, N. and McAdam, D. (2012) A Theory of Fields, Oxford Scholarship Online.

Groenenberg, H. et al. (2008) Climate, Energy Security and Innovation: An assessment of EU energy policy objectives., The Hague: ECN.

Heclo, H. (1978) 'Issue networks and the executive establishment', Public Adm. Concepts Cases 413: 46-57.

Holyoke, T. T. (2009) 'Interest group competition and coalition formation', American Journal of Political Science 53(2): 360-375.

Hone, D. (2017) Putting the Genie Back: Solving the Climate and Energy Dilemma, Bingley: Emerald.

IETA (2012) Briefing on the EU's Emissions Trading Scheme.

IPCC (2014) Climate Change 2014 Synthesis Report Summary Chapter for Policymakers, 2014, doi:10.1017/CBO9781107415324.

Jacobsson, S. et al. (2009) 'EU renewable energy support policy: Faith or facts?', Energy Policy 37(6): 2143-2146.

Jevnaker, T. and Wettestad, J. (2017) 'Ratcheting Up Carbon Trade: The Politics of Reforming EU Emissions Trading', Global Environmental Politics 17(2): 105-124.

Juergens, I., Barreiro-Hurlé, J. and Vasa, A. (2013) 'Identifying carbon leakage sectors in the EU ETS and implications of results', Climate Policy 13(1): 89-109.

Kashima, Y., Paladino, A. and Margetts, E. A. (2014) 'Environmentalist identity and 
Accepted to Journal of European Public Policy, 01/01/2019

environmental striving', Journal of Environmental Psychology 38: 64-75.

Keating, D (2012) Poland blocks EU's low-carbon roadmap, 2012, politico.eu, available at https://www.politico.eu/article/poland-blocks-eus-low-carbon-roadmap/ (accessed November 2018).

Lasswell, H. D. (1936) Politics: Who Gets What, When, how, New York: McGraw-Hill.

Lauber, V. and Schenner, E. (2011) 'The struggle over support schemes for renewable electricity in the european union: A discursive-institutionalist analysis', Environmental Politics 20(4): 508-527.

Lincoln, Y. S. and Guba, E. G. (1985) Naturalistic Inquiry, Newbury Park, London, New Delhi: SAGE.

Lorenzoni, I. and Benson, D. (2014) 'Radical institutional change in environmental governance: Explaining the origins of the UK Climate Change Act 2008 through discursive and streams perspectives', Global Environmental Change 29: 10-21.

Mahoney, C. (2007) 'Networking vs. allying: the decision of interest groups to join coalitions in the US and the EU', Journal of European Public Policy 14(3): 366-383.

Meckling, J. (2011a) Carbon coalitions: Business, climate politics, and the rise of emissions trading, Cambridge, Massachusetts: MIT Press.

Meckling, J. (2011b) 'The globalization of carbon trading: transnational business coalitions in climate politics', Global Environmental Politics 11(2): 26-50.

Mintrom, M. and Luetjens, J. (2017) 'Policy entrepreneurs and problem framing: The case of climate change', Environment and Planning C: Politics and Space 1-16.

Mintrom, M. and Norman, P. (2009) 'Policy Entrepreneurship and Policy Change', Policy Studies Journal 37(4): 649-667.

Mintrom, M. and Thomas, M. (2018) 'Policy entrepreneurs and collaborative action: pursuit of the sustainable development goals', Int. J. Entrepreneurial Venturing 10(2): 153-171.

Mitchell, C., Bauknecht, D. and Connor, P. M. (2006) 'Effectiveness through risk reduction: a comparison of the renewable obligation in England and Wales and the feed-in system in Germany', Energy Policy 34(3): 297-305.

Nye, M. and Owens, S. (2008) 'Creating the UK emission trading scheme: Motives and 
Accepted to Journal of European Public Policy, 01/01/2019

symbolic politics', European Environment 18(1): 1-15.

Oberthür, S. (2011) 'The European Union's Performance in the International Climate Change Regime', Journal of European Integration 33: 667-682.

Phinney, R. (2017) Strange bedfellows: interest group coalitions, diverse partners, and influence in American social policy, Cambridge: Cambridge University Press.

Prudham, S. (2009) 'Pimping climate change: Richard Branson, global warming, and the performance of green capitalism', Environment and Planning A 41(7): 1594-1613.

Schmidt, V. A. (2002) 'Does Discourse Matter in the Politics of Welfare State Adjustment?', Comparative Political Studies 35(2): 168-193.

Schmidt, V. A. (2008) 'Discursive Institutionalism: The Explanatory Power of Ideas and Discourse', Annual Review of Political Science 11(1): 303-326.

Schmidt, V. A. (2010) 'Taking ideas and discourse seriously: explaining change through discursive institutionalism as the fourth "new institutionalism", European Political Science Review 2(01): 1-25.

Schmidt, V. A. (2013) 'Democracy and Legitimacy in the European Union Revisited: Input, Output and "Throughput", Political Studies 61(1): 2-22.

Schmidt, V. A. (2014) 'Speaking to the markets or to the people? A discursive institutionalist analysis of the EU's Sovereign debt crisis', British Journal of Politics and International Relations 16(1): 188-209.

Schmidt, V. A. (2017) 'Theorizing Ideas and Discourse in Political Science: Intersubjectivity, Neo-Institutionalisms, and the Power of Ideas', Critical Review 29(2): 248-263.

Schmidt, V. A. and Radaelli, C. M. (2004) 'Policy change and discourse in Europe: Conceptual and methodological issues', West European Politics 27(2): 183-210.

Shenton, A. (2004) 'Strategies for ensuring trustworthiness in qualitative research projects', Education for information 22: 63-75.

Skjærseth, J. B. and Wettestad, J. (2010) 'Fixing the EU emissions trading system? Understanding the post-2012 changes', Global Environmental Politics 10(4): 101-123.

The Economist (2013) ETS, RIP?, 2013, available at https://www.economist.com/finance-andeconomics/2013/04/20/ets-rip (accessed July 2018). 
Accepted to Journal of European Public Policy, 01/01/2019

The Royal Society (2017) Climate updates: What have we learnt since the IPCC 5th Assessment Report?, London: The Royal Society.

Wettestad, J. (2009) 'EU energy-intensive industries and emission trading: Losers becoming winners?', Environmental Policy and Governance 19(5): 309-320.

Wettestad, J. (2014) 'Rescuing EU Emissions Trading: Mission Impossible?', Global Environmental Politics 14(2): 64-81.

Wettestad, J. and Jevnaker, T. (2016) Rescuing EU Emissions Trading: The Climate Policy Flagship, London: Palgrave Macmillan.

Woerdman, E. (2004) 'Path-dependent climate policy: The history and future of emissions trading in Europe', European Environment 14(5): 261-275. 